Terakreditasi: SK No.: 60/E/KPT/2016

Website : http://ejournal.undip.ac.id/index.php/reaktor/

Reaktor, Vol. 17 No. 2, Juni Tahun 2017, Hal. 67-73

\title{
Uji Kinerja Burner dan Tabung Reaktor Flame Untuk Proses Spray Pyrolysis
}

\author{
Darmawan Hidayat $^{1, *)}$, Ganjar Nurohman ${ }^{2)}$, Setianto ${ }^{2)}$, Bambang Mukti Wibawa'), dan \\ Nendi Suhendi ${ }^{1)}$ \\ ${ }^{1)}$ Departemen Teknik Elektro, FMIPA, Universitas Padjadjaran \\ Jl. Raya Bandung-Sumedang 45363 Km. 21 Jatinangor, Sumedang \\ Telp./Fax. (022)84288888 / (022) 84288889 \\ ${ }^{2)}$ Departemen Fisika, FMIPA, Universitas Padjadjaran \\ Jl. Raya Bandung-Sumedang 45363 Km. 21 Jatinangor, Sumedang \\ Telp./Fax. (022)84288888 / (022) 84288889 \\ ${ }^{*}$ Penulis korespondensi: darmawan.hidayat@unpad.ac.id
}

\begin{abstract}
PERFORMANCE EVALUATION OF BURNER AND THE REACTOR TUBE OF FLAME FOR A SPRAY PYROLYSIS PROCESS. Flame spray pyrolysis is a versatile process in the syntheses of various functional materials. This work reports the performance of a diffusion flame built from a coaxial burner and a Pyrex-glass tube reactor with respect to the relatively low propane flow rates (0.1-0.8 L/min). The burner comprised of three cylindrically tubes with three inlets for fuel (propane), oxidant (oxygen) and precursor aerosol. Three flame parameters were measured, i.e. the flame height, flame temperature and reactor temperature profile, respectively. The test results showed the increase of the flame height and temperature with increasing of propane flow rate. The temperature profile measurements showed the decreasing as the height above burner increased; and temperature profile increased at the increasing propane flow rate. The reactor temperature was in the range of 36$190{ }^{\circ} \mathrm{C}$ at low propane flow rates of 0.1-0.8 L/min. In conclusion, control of flame process parameters could be conducted by controlling of propane flow rate.
\end{abstract}

Keywords: diffusion flame burner; spray pyrolysis; flame reactor; electronic material syntheses

\begin{abstract}
Abstrak
Pirolisis flame spray merupakan proses yang banyak digunakan untuk keperluan sintesis bahan-bahan fungsional. Makalah ini melaporkan kinerja sebuah reaktor flame difusi yang dibangun dari sebuah pembakar (burner) dan tabung reaktor silinder. Pembakar dibangun dari tiga buah silinder stainless steel yang dipasang koaksial sebagai saluran bahan bakar propana, oksidator oksigen dan aerosol prekursor. Tiga parameter proses flame yang diuji adalah tinggi flame, temperatur flame dan profil temperatur tabung reaktor. Hasil pengujian menunjukkan bahwa seiring kenaikan laju alir propana, tinggi dan temperatur flame meningkat. Pengukuran profil temperatur menunjukkan penurunan seiring kenaikan posisi dari ujung-atas pembakar; dan temperatur profil reaktor meningkat seiring dengan kenaikan laju alir propana. Temperatur reaktor berkisar $36-190^{\circ} \mathrm{C}$ pada laju alir propana rendah 0,10,8 L/min. Dapat disimpulkan bahwa pengontrolan parameter-parameter proses flame dapat dilakukan dengan pengaturan laju alir propana.
\end{abstract}

Kata kunci: diffusion flame burner; proses spray pyrolysis; reaktor flame; sintesis bahan elektronik 
How to Cite This Article: Hidayat, D., Nurohman, G., Setianto, Wibawa, B.M., dan Suhendi, N., (2017), Uji Kinerja Burner dan Tabung Reaktor Flame Untuk Proses Spray Pyrolysis, Reaktor, 17(2), 67-73, http://dx.doi.org/10.14710/reaktor.17.2.67-73

\section{PENDAHULUAN}

Dalam proses fabrikasi berbagai sensor besaran fisis seperti sensor potensiometrik, sensor gas, sensor magnetik, tekanan dan sejenisnya, bahan elektronik menjadi komponen utama yang mengubah besaran fisis menjadi besaran listrik (Volkov dkk., 2017; Liewhiran dkk., 2013; Mirzaei dkk., 2016). Beberapa bahan menunjukkan sifat unggul untuk keperluan sensor seperti grafena oksida dan $\mathrm{WO}_{3}$ untuk sensor tekanan (Wan dkk., 2017; Hidayat dkk., 2010a), aloy Zn-In-O nanopartikel dan $\mathrm{MnO}-\mathrm{ZnO}$ untuk sensor gas $\mathrm{NO}_{2}$ (Samerjai dkk., 2012; Tamaekong dkk., 2014), beberapa logam oksida semikonduktor untuk sensor untuk gas-gas mudah terbakar (Samerjai dkk., 2012) dan gas $\mathrm{H}_{2} \mathrm{~S}$ (Sukunta dkk., 2017), $\mathrm{SnO}_{2}-\mathrm{Pt}$ untuk sensor sensitif gas $\mathrm{H}_{2}$, dan $\mathrm{WO}_{3}$ untuk fotokatalis (Hidayat dkk., 2010).

Terdapat beberapa metode untuk sintesis material-material sensor tersebut, seperti: proses hidrotermal, sol-gel dan reaksi zat padat (Nathan dan Boby, 2017). Namun, metode-metode tersebut memiliki keterbatasan pada beberapa parameter karakeristik material, seperti: pengontrolan ukuran partikel, proses bersifat batch dan membutuhkan banyak energi dan waktu sehingga menjadi kendala dalam penerapan di industri.

Di samping proses-proses tersebut, proses flame memberikan metode sintesis material sensor dengan parameter ukuran partikel, morfologi dan kristalinitas yang terkontrol (Rudin dkk., 2013; Gröhn dkk., 2012; Setiawan $\mathrm{dkk}$, 2016). Beberapa material fungsional dengan sifat yang lebih baik telah berhasil disintesis melalui proses flame, yaitu: tungsten oksida nanopartikel, barium titanat, dan yttria (Hidayat dkk., 2010b; Purwanto dkk., 2009). Proses flame memberikan berbagai keunggulan yang relatif tidak tersedia pada proses lainnya seperti waktu proses yang lebih singkat dan operasi kontinyu (Kelesidis dkk., 2017; Strobel dan Pratsinis, 2007).

Oleh karena itu, proses flame sangat efektif untuk dikembangkan guna keperluan-keperluan sintesis bahan sensor. Makalah ini melaporkan kinerja bagian pembakar (burner) dan tabung reaktor proses flame hasil pengembangan penelitian seperti ditunjukkan oleh blok garis putus-putus pada Gambar 1 yang diproyeksikan untuk aplikasi fabrikasi sensorsensor besaran fisis.

\section{BAHAN DAN METODE}

\section{Proses Flame Spray Pyrolysis}

Gambar 1 memperlihatkan proses flame tipikal yang dibangun (Purwanto dkk., 2009; Hidayat dkk., 2010a). Proses ini terdiri dari gas bahan bakar dan oksidator, pengontrol aliran gas, pembakar (burner), reaktor, penangkap air, penangkap partikel dan pompa alir. Proses flame ini berfungsi untuk sintesis partikel padatan (powder) dari prekursor cair. Bahan bakar dan oksidator adalah masing-masing propana $\left(\mathrm{C}_{3} \mathrm{H}_{8}\right)$ dan oksigen $\left(\mathrm{O}_{2}\right)$ (dari PT. Samator Gas, Bandung). Struktur proses flame yang dibuat adalah jenis flame difusi (non-premixed/diffusion flame) laminar, dimana pembakaran terjadi di bidang batas antara bahan bakar dan oksidator. Laju pembakaran bahan bakar secara dominan bergantung pada laju difusi bahan bakar.

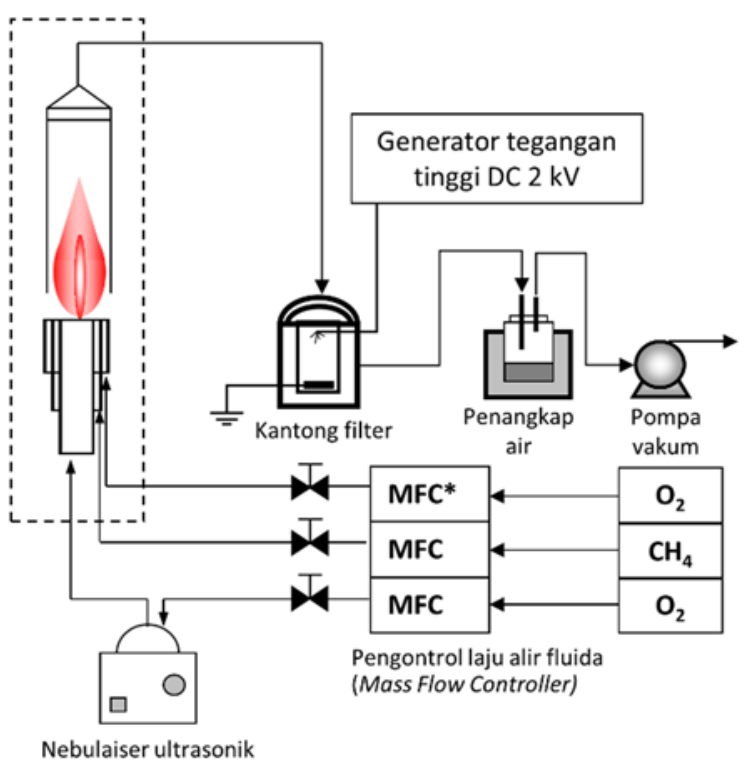

Gambar 1. Proses flame tipikal untuk sintesis partikel bahan fungsional (Purwanto dkk., 2009)

Pada tahap pertama sintesis, nebulaiser ultrasonik mengubah prekursor cair menjadi aerosol prekursor yang selanjutnya dibawa ke bagian saluran tengah pembakar dan tabung reaktor oleh gas pembawa, dimana aerosol prekursor mengalami proses fisika-kimia untuk pembentukan partikel solid yang akan terjebak di penangkap partikel. Uap air hasil proses dikondensasi dan terkumpul di bagian dalam penangkap air sehingga air tidak masuk ke sistem pompa. Setelah seluruh tahap proses lengkap selesai, partikel padatan akan terkumpul di bagian penangkap partikel. Sebagai uji kinerja, laju alir propana dan oksigen dibuat relatif rendah (kurang dari $1 \mathrm{~L} / \mathrm{min}$ ) dan divariasikan masing-masing $0,1-0,8 \mathrm{~L} / \mathrm{min}$ dan $0,5-4,0$ $\mathrm{L} / \mathrm{min}$, dengan perbandingan 1:5 untuk memastikan terjadinya pembakaran sempurna menurut persamaan reaksi 1.

$$
\mathrm{C}_{3} \mathrm{H}_{8}(\mathrm{~g})+5 \mathrm{O}_{2}(\mathrm{~g}) \rightarrow 3 \mathrm{CO}_{2}(\mathrm{~g})+4 \mathrm{H}_{2} \mathrm{O}(\mathrm{g})
$$

Pengaturan laju alir propana dan oksigen dilakukan oleh regulator gas manual tipe udara yang telah dikalibrasi ke laju alir oksigen dan propana. Thermometer laser sight, (Extech Instruments 42570 Dual Laser Infrared Thermometer) digunakan untuk mengukur secara non-kontak temperatur zona flame dan profil temperatur tabung reaktor. 


\section{Rancangan Burner Dan Reaktor}

Geometri sistem pembakar adalah sistem tiga aliran, dibangun secara konsentrik dari tiga silinder stainless steel dengan diameter dalam masing-masing 15, 35 dan 55 mm (Gambar 2a) (Hidayat dkk., 2010a; Kammler dkk., 2001) yang dirancang dapat bertahan hingga suhu $1100^{\circ} \mathrm{C}$. Konfigurasi difusi flame adalah sistem difusi tunggal dimana bahan bakar berada di bagian lebih dalam silinder dan silinder oksigen lebih luar seperti ditunjukkan oleh Gambar 2a (Kammler dkk., 2001; Kang dkk., 2001). Silinder 1 paling dalam berfungsi sebagai jalur aliran aerosol prekursor dari nebulaiser ultrasonik sedangkan silinder 2 dan 3 yang dilengkapi konektor inlet masing-masing berfungsi sebagai pasokan aliran propana dan oksigen (Gambar 2 b dan c). Pembakar dipasang vertikal pada batang pemegang yang dilengkapi penjepit baja (clamp) sehingga penempatan pembakar dapat diatur.

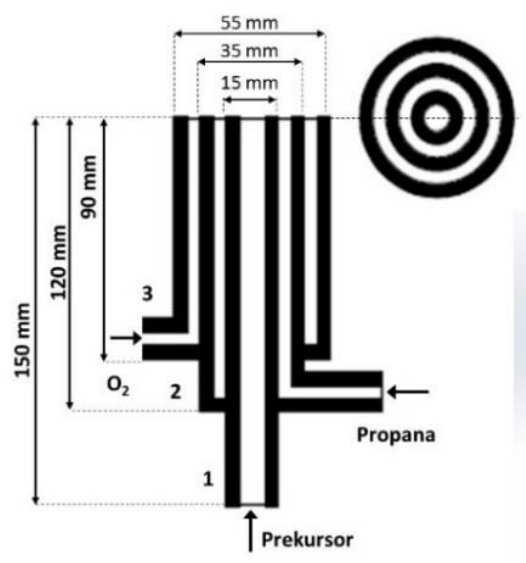

(a)

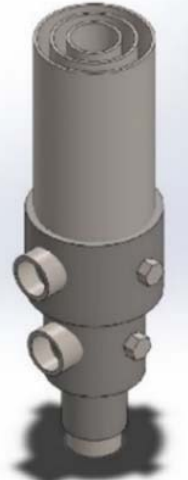

(b)

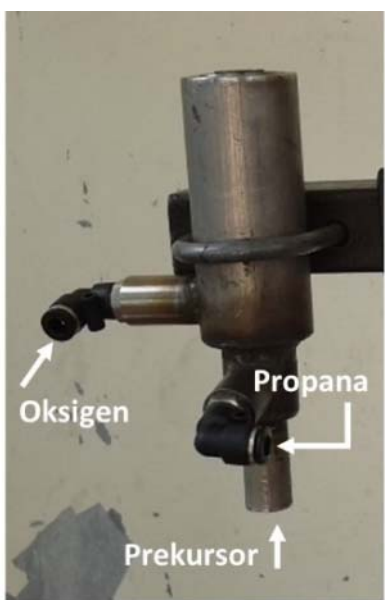

(c)
Gambar 2. Sistem burner tiga aliran, (a) skematik burner, (b) sketsa 3D dan (c) wujud fisik

Reaksi fisika-kimia selanjutnya terjadi di dalam tabung reaktor yang dipasang vertikal segaris di atas pembakar. Geometri tabung reaktor adalah silindris dibuat dari gelas pyrex dengan ketebalan, diameter- dalam, dan tinggi adalah masing-masing 5, 55 dan 750 mm (Gambar 3a). Bentuk ujung atas tabung reaktor adalah konik rata untuk hubungan konektor tabung ke bagian penangkap partikel (Gambar 3b).

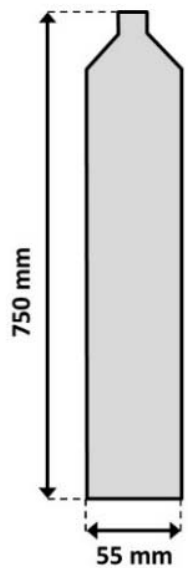

(a)

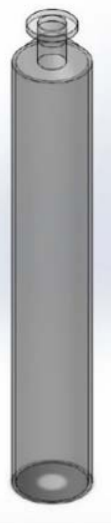

(b)
Gambar 3. Reaktor flame: (a) desain 2D reaktor dan (b) desain 3D reaktor (Purwanto dkk., 2007)

\section{Pengukuran Temperatur Flame dan Profil Temperatur}

Tinggi flame diukur dengan skala penggaris. Pengukuran temperatur titik flame diambil pada empat titik zona flame (Gambar 4a), yaitu: zona kiri flame (titik 1), zona kanan flame (titik 2), zona tengah flame (titik 3), dan zona atas flame (titik 4). Jarak thermometer dari flame adalah 1,5 meter sesuai manual operasi.

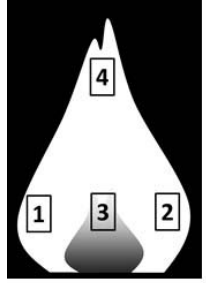

(a)

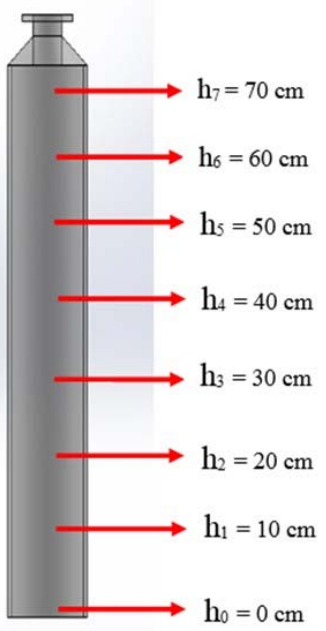

(b)
Gambar 4. Pengukuran temperatur pada proses flame (a) temperatur zona flame, dan (b) (profil) temperatur pada tabung reaktor

Profil temperatur tabung reaktor dilakukan dengan pengukuran temperatur pada titik-titik pusat silinder tabung reaktor vertikal, $h$ mulai dari titik nol di 
ujung bawah tabung. Titik profil pengukuran temperatur meliputi setiap kenaikan $10 \mathrm{~cm}$ sehingga terdapat delapan titik temperatur, $h$ yaitu: $0,10,20,30$, 40, 50, 60, dan $70 \mathrm{~cm}$ untuk setiap satu set profil temperatur (lihat Gambar 4b). Setiap pengukuran satu set profil temperatur reaktor dilakukan pada satu laju alir propana. Selanjutnya, pengukuran profil temperatur diulang dengan laju alir propana, $Q_{f}$, divariasikan $0,1-0,8 \mathrm{~L} / \mathrm{min}$.

\section{HASIL DAN PEMBAHASAN}

Untuk mengetahui kinerja bagian pembakar dan tabung reaktor, tiga parameter pengukuran dilakukan, yaitu: pengaruh laju alir propana terhadap tinggi dan temperatur flame, dan profil temperatur tabung reaktor.

\section{Pengaruh Tinggi Api Terhadap Laju Alir}

Laju reaksi pembakaran proses difusi flame berhubungan langsung dengan jumlah difusi bahan bakar dan oksidator ke zona pembakaran (flame) (Persamaan 2) sehingga tinggi flame sebanding dengan laju alir bahan bakar (Glassman dan Yetter, 2008).

$$
y_{F}=\frac{Q_{f}}{\pi \cdot D}
$$

Tinggi flame merupakan salah satu parameter kinerja pada proses pirolisis flame spray sehingga kontrol tinggi flame menjadi penting dalam proses pembentukan partikel. Peningkatan tinggi flame menentukan waktu pertumbuhan (growth) dan waktu sintering partikel, sehingga dapat menentukan ukuran partikel akhir yang dihasilkan (Kammler dkk., 2001; Rudin dkk., 2013). Peningkatan pasokan oksigen dan bahan bakar juga menentukan tinggi flame. Purwanto dkk. (2006) melaporkan bahwa tinggi flame dapat diatur melalui pengaturan laju alir bahan bakar metana. Gambar 5 memperlihatkan variasi tinggi flame terhadap laju alir propana. Ketika variasi laju alir bahan bakar 0,1-0,8 L/min, variasi tinggi flame adalah 18-286 $\mathrm{mm}$. Pada laju alir propana 0,1 dan $0,2 \mathrm{~L} / \mathrm{min}$, tinggi flame adalah 18 dan $62 \mathrm{~mm}$. Ketika laju alir dinaikkan menjadi 0,3 hingga $0,8 \mathrm{~L} / \mathrm{min}$, tinggi flame secara signifikan meningkat 183 hingga $286 \mathrm{~mm}$. Hasil pengukuran menunjukkan bahwa tinggi flame semakin besar seiring kenaikan laju alir bahan bakar sesuai dengan Persamaan 2. Xu dkk. (2016) juga melaporkan bahwa tinggi flame semakin meningkat ketika laju bahan bakar diperbesar. Teori difusi gas menyebutkan bahwa tinggi flame berbanding lurus dengan laju alir dan tidak bergantung pada diameter silinder pembakar (Glassman dan Yetter, 2008). Berdasarkan hukum kontinyuitas dinamika fluida, laju alir yang lebih tinggi menyebabkan kenaikan kecepatan partikel-partikel fluida. Tinggi flame juga bergantung pada kecepatan gas bahan bakar, yaitu kecepatan rendah menghasilkan flame pendek sedangkan kecepatan tinggi menghasilkan flame lebih tinggi. Oleh karena itu, ketika laju alir bahan bakar propana dinaikkan maka menyebabkan kenaikan tinggi flame. Hasil ini sejalan dengan korelasi Roper yang menyatakan estimasi tinggi flame untuk pembakar sirkular merupakan fungsi dari laju alir volumetrik bahan bakar (Turns, 2000).

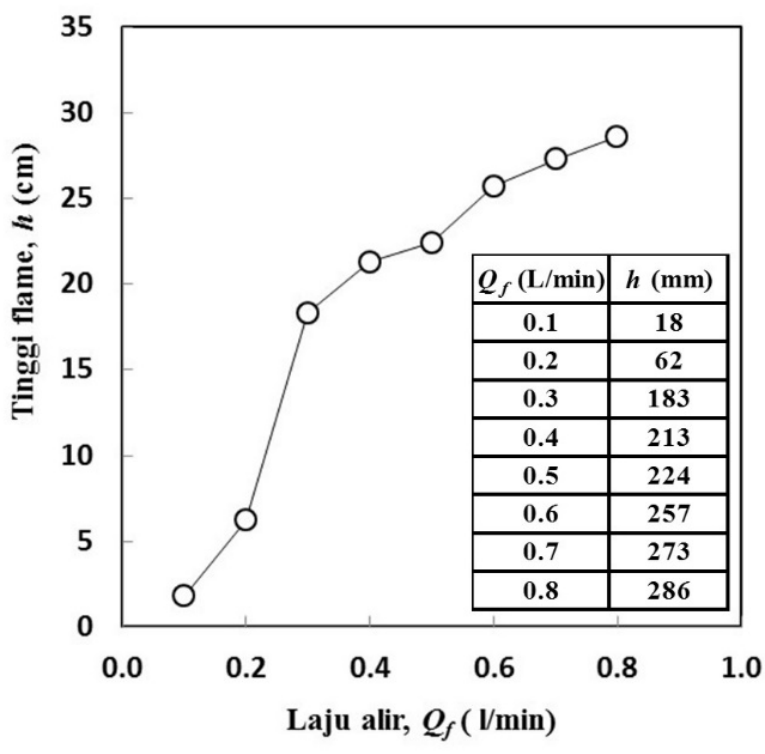

Gambar 5. Pengaruh laju alir bahan bakar terhadap tinggi flame

Bentuk flame dan empat variasi tinggi flame ditampilkan pada Gambar 6. Tampak bahwa tinggi flame pada laju alir propana 0,4 hingga $0,8 \mathrm{~L} / \mathrm{min}$ jauh lebih tinggi dibandingkan dengan tinggi flame pada laju alir propana $0,1 \mathrm{~L} / \mathrm{min}$.

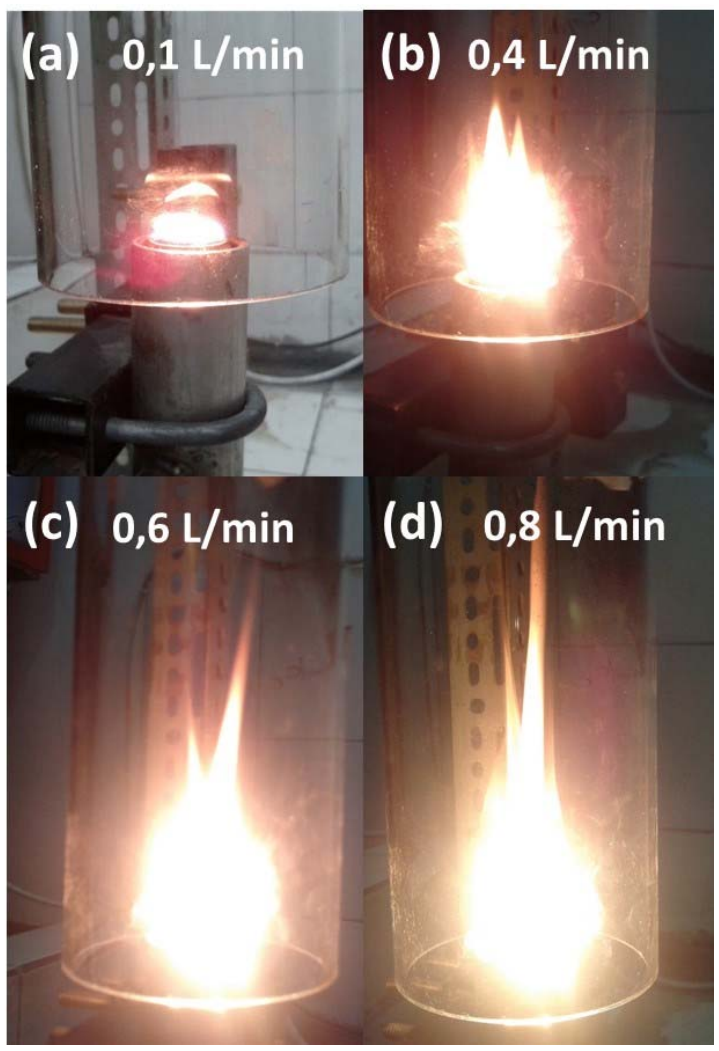

Gambar 6. Foto flame pada laju alir propana (a) 0,1 , (b) 0,4 , (c) 0,6 , dan (d) $0,8 \mathrm{~L} / \mathrm{min}$ 


\section{Temperatur pada Zona Api}

Kang dkk. (2001) melaporkan temperatur flame merupakan faktor penting pada proses flame spray pyrolysis untuk kontrol morfologi dan sifat optik sintesis partikel $\mathrm{Y}_{2} \mathrm{O}_{3}$ :Eu. Bahkan kontrol struktur kristal juga dapat diatur dengan pengaturan temperatur flame.

Pada makalah ini, pengukuran temperatur zona flame merupakan pengukuran temperatur pada titiktitik di dalam flame. Tujuan pengukuran ini adalah untuk mengamati distribusi temperatur dalam flame terhadap laju alir bahan bakar. Dengan mengetahui pengaruh laju alir propana terhadap distribusi temperatur flame, maka proses flame dapat diatur melalui pengaturan laju alir bahan bakar.

Gambar 7 menunjukkan secara umum bahwa temperatur seluruh empat titik meningkat seiring peningkatan laju alir propana. Temperatur zona atas flame (titik 4) adalah paling tinggi dibandingkan zona kiri, kanan, dan tengah flame (inset Gambar 7). Pada setiap satu nilai laju alir propana, perbedaan temperatur antara titik-titik zona flame berkisar $\sim 1-8^{\circ} \mathrm{C}$. Nilai variasi perbedaan ini relatif tidak begitu signifikan dalam operasi sintesis reaktor flame yang berkisar antara $400-2000^{\circ} \mathrm{C}$ (Widiyastuti, 2010). Dengan kata lain, berdasarkan hasil pengukuran Gambar 7 terlihat bahwa temperatur flame dapat dikontrol melalui pengaturan laju alir propana. Estimasi temperatur flame oleh Xu dkk. (2016) dilakukan dengan menghitung kontur radial temperatur di atas pembakar. Hasilnya mengungkapkan bahwa temperatur tertinggi flame meningkat linear terhadap kenaikan laju alir bahan bakar. Pengaruh laju alir terhadap temperatur dapat dijelaskan seperti berikut, ketika laju alir bahan bakar naik, jumlah volumetrik bahan bakar yang bereaksi semakin banyak sehingga menghasilkan panas yang lebih banyak, dan mengakibatkan kenaikan temperatur flame.

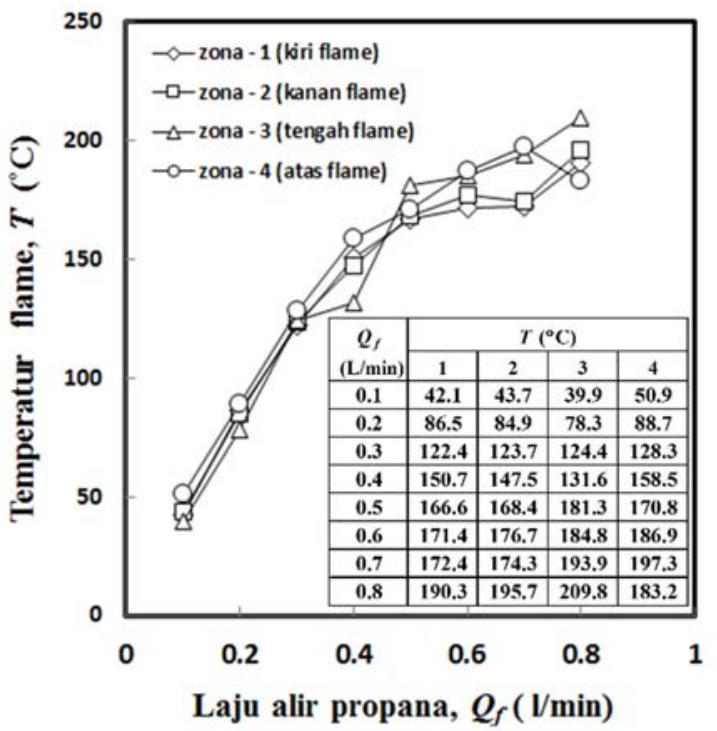

Gambar 7. Temperatur empat titik zona flame variasi terhadap laju alir propana

\section{Profil Temperatur Reaktor}

Profil temperatur reaktor menjadi parameter penting dalam proses flame karena terkait dengan proses pembentukan partikel sepanjang jalur lintasan partikulat, mulai dari fasa partikulat droplet hingga partikel padatan (Widiyastuti, 2010). Profil temperatur pada tabung reaktor dengan variasi laju alir propana diperlihatkan pada Gambar 8. Pada satu nilai laju alir propana, temperatur semakin kecil seiring kenaikan lokasi titik. Dengan kata lain, temperatur menurun pada titik-titik yang semakin tinggi di atas pembakar. Pada laju alir yang lebih tinggi $(0,3-0,8 \mathrm{~L} / \mathrm{min})$ temperatur di ketinggian $10 \mathrm{~cm}$ ke $20 \mathrm{~cm}$ menurun secara drastis. Hal ini menunjukkan bahwa proses difusi bahan bakar dan oksigen secara dominan terjadi di lokasi sekitar 0-10 $\mathrm{cm}$ pembakaran flame.

Secara umum, Gambar 8 memperlihatkan bahwa dari setiap pengukuran temperatur pada setiap jarak ketinggian $h$, di atas pembakar, selalu mengalami kenaikan temperatur sebanding dengan kenaikan laju alir bahan bakar. Temperatur tertinggi reaktor ada pada titik $h$ ketinggian $10 \mathrm{~cm}$ dan temperatur terendah ada pada reaktor dengan titik $70 \mathrm{~cm}$. Semakin jauh titik ketinggian maka temperatur semakin rendah. Sesuai dengan hasil sistem reaktor premixed yang dilaporkan oleh Kramler dkk. (2001) bahwa seiring lokasi ketinggian titik, temperatur naik dengan cepat dan menurun perlahan yang merupakan profil tipikal reaktor flame.

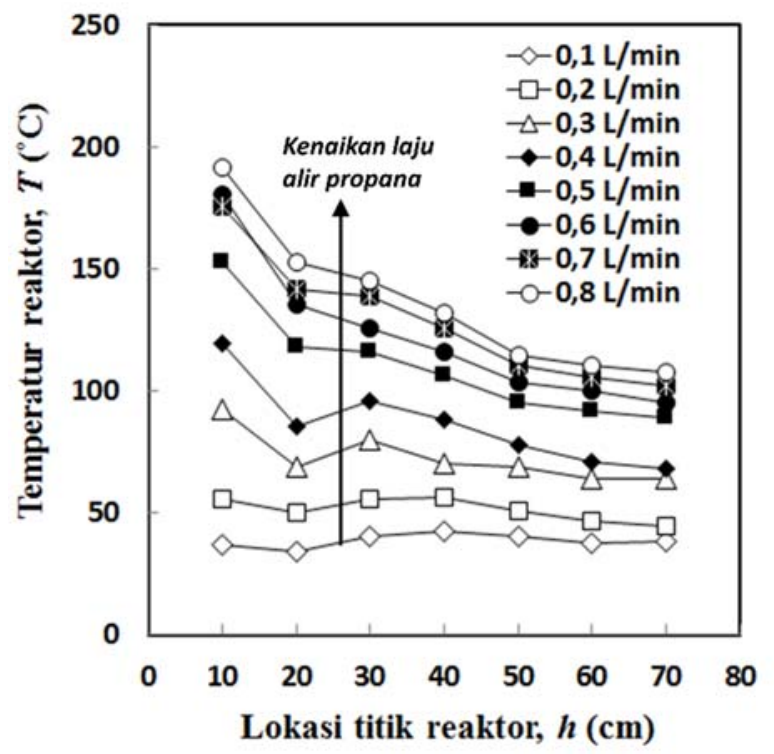

Gambar 8. Profil temperatur tabung reaktor pada berbagai laju alir propana

\section{KESIMPULAN}

Berdasarkan hasil pengujian kinerja pembakar dan tabung reaktor flame pada laju-alir-uji propana rendah, $0,1-0,8 \mathrm{~L} / \mathrm{min}$ dapat disimpulkan bahwa tinggi flame sebanding dengan laju alir propana. Temperatur titik-titik zona flame (zona kiri flame, zona kanan flame, zona tengah flame, dan zona atas flame) relatif terdistribusi merata dan sebanding dengan laju alir propana. Profil temperatur reaktor menunjukkan bahwa 
temperatur menurun seiring posisi ketinggian di dalam tabung reaktor. Profil temperatur meningkat seiring dengan kenaikan laju alir propana. Dari pengujian, dapat disimpulkan bahwa semakin besar laju alir bahan bakar maka akan semakin besar pula flame yang dihasilkan, baik itu tinggi flame, temperatur pada zona flame, dan temperatur pada reaktor.

\section{DAFTAR NOTASI}

$y_{F}$ tinggi flame $(\mathrm{mm})$

$Q_{f}$ laju alir bahan bakar (L/min)

$D$ diameter pembakar (mm)

\section{DAFTAR PUSTAKA}

Glassman, I. and Yetter, R.A., (2008), Combustion, $4^{\text {th }}$, Elsevier Inc., 30 Corporate Drive, Suite 400, Burlington, MA 01803, USA, pp. 325-326.

Gröhn, A.J., Pratsinis, S.E., and Wegner, K., (2012), Fluid-Particle Dynamics during Combustion Spray Aerosol Synthesis of $\mathrm{ZrO}_{2}$, Chemical Engineering Journal, 191, pp. 491-502.

Hidayat, D., Purwanto, A., Wang, W.N., and Okuyama, K., (2010a), Preparation of Size-Controlled Tungsten Oxide Nanoparticles and Evaluation of their Adsorption Performance, Materials Research Bulletin, 45, pp. 165-173.

Hidayat, D., Widiyastuti, W., Ogi, T., and Okuyama, K., (2010b), Droplet Generation and Nanoparticle Formation in Low-Pressure Spray Pyrolysis, Aerosol Science and Technology, 44, pp. 692-705.

Kammler, H.K., Mädler, L., and Pratsinis, S.E., (2001), Flame Synthesis of Nanoparticles, Chem. Eng. Technol., 24(6), pp. 583-596.

Kang, Y.C., Seo, D.J., Park, S.B., and Park, H.D., (2001), Morphological and Optical Characteristics of $\mathrm{Y}_{2} \mathrm{O}_{3}$ :Eu Phosphor Particles Prepared by Flame Spray Pyrolysis, Japan Journal of Applied Physics, 40, pp. 4083-4086.

Kelesidis, G.A., Goudeli, E., and Pratsinis, S.E., (2017), Flame Synthesis of Functional Nanostructured Materials and Devices: Surface Growth and Aggregation, Proceedings of the Combustion Institute, 36, pp. 29-50.

Liewhiran, C., Tamaekong, N., Wisitsoraat, A., Tuantranont, A., and Phanichphant, S., (2013), Ultrasensitive $\mathrm{H}_{2}$ Sensors Based on Flame-Spray-Made Pdloaded $\mathrm{SnO}_{2}$ Sensing Films, Sensors and Actuators B, 176, pp. 893-905.

Mirzaei, A., Janghorban, K., Hashemi, B., Bonyani, M., Leonardi, S.G., and Neri, G., (2016), Highly Stable and Selective Ethanol Sensor Based on $\alpha-\mathrm{Fe}_{2} \mathrm{O}_{3}$ Nanoparticles Prepared by Pechini Sol-Gel Methods, Ceramics International, 42, pp. 6136-6144.
Nathan, D.M.G.T. and Boby, S.J.M., (2017), Hydrothermal Preparation of Hematite Nanotubes/Reduced Graphene Oxide Nanocomposites as Electrode Material for High Performance Supercapacitors, Journal of Alloys and Compounds, 700, pp. 67-74.

Purwanto, A., Lenggoro, I.W., Chang, H., and Okuyama, K., (2006), Preparation of Submicron- and Nanometer- Sized Particles of $\mathrm{Y}_{2} \mathrm{O}_{3}: \mathrm{Eu}^{3+}$ by Flame Spray Pyrolysis Using Ultrasonic and Two Fluid Atomizers, Journal of Chemical Engineering of Japan, 39(1), pp. 68-76.

Purwanto, A., Wang, W.-N., Lenggoro, I.W., and Okuyama, K., (2007), Formation and Luminescence Enhancement of Agglomerate-Free YAG: $\mathrm{Ce}^{3+}$ Submicrometer Particles by Flame-Assisted Spray Pyrolysis, Journal of the Electrochemical Society, 154 (3), pp. J91-J96.

Purwanto, A., Widiyandari, H., Hidayat, D., Iskandar, F., and Okuyama, K., (2009), Facile Method for the Fabrication of Vertically Aligned ITO Nanopillars with Excellent Properties, Chemistry of Materials, 21(18), pp. 4087-4089.

Rudin, T., Wegner, K., and Pratsinis, S.E., (2013), Towards Carbon-Free Flame Spray Synthesis of Homogeneous Oxide Nanoparticles from Aqueous Solutions, Advanced Powder Technology, 24, pp. 632642 .

Samerjai, T., Tamaekong, N., Wetchakun, K., Kruefu, V., Liewhiran, C., Siriwong, C., Wisitsoraat, A., and Phanichphat, S., (2012), Flame-Spray-Made MetalLoaded Semiconducting Metal Oxides Thick Films for Flammable Gas Sensing, Sensors and Actuators B, 171, pp. 43-61.

Setiawan, A., Widiyastuti, Winardi, S., dan Nugroho, A., (2016), Sintesis Biomaterial Hydroxyapatite dengan Proses Flame Spray Pyrolysis disertai Penambahan Aditif Organik, Reaktor, 16(4), pp. 189198 ,

Strobel, R. and Pratsinis, S.E., (2007), Flame Aerosol Synthesis of Smart Nanostructured Materials, J. Mater. Chem., 17, pp. 4743-4756.

Sukunta, J., Wisitsoraat, A., Tuantranont, A., Phanichphant, S., and Liewhiran, C., (2017), HighlySensitive $\mathrm{H}_{2} \mathrm{~S}$ Sensors Based on Flame-Made VSubstituted $\mathrm{SnO}_{2}$ Sensing Films, Sensors and Actuators $B, 242$, pp. 1095-1107.

Tamaekong, N., Liewhiran, C., Wisitsoraat, A., Tuantranont, A., and Phanichphant, S., (2014), $\mathrm{NO}_{2}$ Sensing Properties of Flame-Made $\mathrm{MnO}_{\mathrm{x}}$-Loaded ZnO-Nanoparticle Thick Film, Sensors and Actuators B, 204, pp. 239-249. 
Turns, S.R., (2000). An Introduction to Combustion. Concepts and Applications. Mcgraw-Hill Publ.Comp. pp. 305-318.

Volkov, A., Gorbova, E., Vylkova, A., Medvedev, D., Demin, A., and Tsiakaras, P., (2017), Design and Applications of Potentiometric Sensors Based on Proton-Conducting Ceramic Materials: A Brief Review, Sensors and Actuators B, 244, pp. 1004-1015.

Wan, S., Bi, H., Zhou, Y., Xie, X., Su, S., Yin, K., and Sun, L., (2017), Graphene Oxide as High-Performance Dielectric Materials for Capacitive Pressure Sensors, Carbon, 114, pp. 209-216.
Widiyastuti, W., Hidayat, D., Purwanto, A., Iskandar, F., and Okuyama, K., (2010), Particle Dynamics Simulation of Nanoparticle Formation in A Flame Reactor Using A Polydispersed Submicron-Sized Solid Precursor, Chemical Engineering Journal, 158, pp. 362-367.

Xu, T., Chen, Q., Zhang, B., Lu, S., Mo, D., Zhang, Z., and Gao, X., (2016), Effects of Electric Field on MicroScale Flame Properties of Biobutanol Fuel, Scientific Reports 6: 32938, pp. 1-11. 